TEME, г. XLIII, бр. 3, јул - септембар 2019, стр. 807-824

\begin{tabular}{lr}
\hline Оригинални научни рад & https://doi.org/10.22190/TEME190617049J \\
Примљено: 17.6. 2019. & UDK 502.131.1:339.137
\end{tabular}

UDK 502.131.1:339.137

Ревидирана верзија: 12. 10. 2019.

Одобрено за штампу: 20. 10. 2019.

\title{
THE EFFECTS OF APPLYING STATISTICAL METHODS IN GLOBAL SUSTAINABLE COMPETITIVENESS INDEX CREATION
}

\author{
Vesna Janković-Milić*, Sonja Jovanović \\ University of Niš, Faculty of Economics, Niš, Serbia \\ vesna.jankovic@eknfak.ni.ac.rs
}

\begin{abstract}
Linking the concept of sustainable development, as demanding per capita prosperity, does not decline over a long period of time, and the concept of competitiveness which reflects the level of productivity of national economies is a new approach to development called sustainable competitiveness. The care for the scarcity of resources and the preservation of their base so that future generations will have the same level of well-being as today's generation have, requires the incorporation of environmental and social issues and problems into the concept of competitiveness. In this way, a new context of competitiveness analysis is introduced and it meets the challenges of the concept of sustainable development.

The methodology of the composite index of sustainable competitiveness was first developed by the World Economic Forum (WEF), followed by organizations such as SolAbility - Sustainable Intelligence. SolAbility methodology of Global Sustainable Competitiveness Index (GSCI) creation is the subject of research in this paper. The aim of the research is to suggest a new methodology for calculating GSCI based on different weights assigned to the pillars included in the Index. The paper concludes that the highest relative importance in the structure of the GSCI belongs to the Intellectual capital dimension. The originality of this work is reflected in the creation of a new ranking of countries in terms of sustainable competitiveness. An analysis of possible changes in the ranking list is a good basis for a new analysis of the sustainable competitiveness of countries, in which some of the professional and statistical rules comments on its calculation methodology are accepted.
\end{abstract}

Key words: $\quad$ sustainable development, competitiveness, composite indexes, weighting. 
808

\title{
ЕФЕКТИ ПРИМЕНЕ СТАТИСТИЧКИХ МЕТОДА У КРЕИРАЬУ ГЛОБАЛНОГ ИНДЕКСА ОДРЖИВЕ КОНКУРЕНТНОСТИ
}

\begin{abstract}
Апстракт
Повезивање концепта одрживог развоја, као захтева да се благостање по глави становника не смањује током дужег временског периода, и концепта конкурентности, који одражава ниво продуктивности националних економија, представља нови приступ развоју назван одржива конкурентност. Брига за оскудност ресурса и очување њихове базе, како би будуће генерације имале исти ниво благостања као и данашња генерација, захтева укључивање еколошких и социјалних питања и проблема у концепт конкурентности. На овај начин уведен је нови контекст анализе конкурентности који истовремено излази у сусрет изазовима концепта одрживог развоја.

Методологију композитног индекса одрживе конкурентности први је развио Светски економски форум (World Economic Forum - WEF), а затим су се придружиле и друге организације као што је SolAbility - Sustainable Intelligence. Методологија SolAbility, примењена при креирању Глобалног индекса одрживе конкурентности (Global Sustainable Competitiveness Index - GSCI), представља предмет истраживања у овом раду. Циљ истраживања је предлагање нове методологије за израчунавање GSCI на основу различитих пондера који се додељују стубовима укљученим у Индекс. У раду се закључује да највиши релативни значај у структури GSCI припада димензији интелектуалног капитала. Оригиналност овог рада огледа се у креирању нове ранг-листе земаља према достигнутом нивоу одрживе конкурентности. Анализа могућих промена на ранг-листи добра је основа за примену нове анализе у приступу одрживе конкурентности земаља, у којој би се узела у обзир критичка мишљења и ставови о методологији израчунавања композитних показатеља, као што је и GSCI.
\end{abstract}

Кључне речи: одрживи развој, конкурентност, композитни индекс, пондерисање.

\section{INTRODUCTION}

Sustainable development represents a contemporary concept of development incorporated into all policies, strategies and development programs. Creating indicators that show the state and trends in the field of economic development, environmental protection, people's wellbeing, and wider, sustainable development, is an important prerequisite for pursuing economic, social and environmental development policies. Indicators of sustainable development and sustainable competitiveness are an effective instrument in the strategic determination of countries to consistently implement the concept of sustainable development. In order to assess progress in achieving competitiveness, through the integration of all three dimensions of sustainable development - environmental, economic and social, SolAbility has developed the Global Sustainable Competitiveness Index (GSCI).

This model of competitiveness gives equal importance to all indicators included in the analysis. However, the literature raises the 
question of whether all factors included in Index are equally important for achieving sustainable development. This remark is the starting point for the research in this paper.

The subject of research in this paper is the methodology for calculating the Global Sustainable Competitiveness Index. The aim is to present a recommendation for a new methodology for calculating Sustainable Competitiveness Index based on different weighting, or adding value to the pillars included in the Index. The information base is data of the SolAbility. For this research the following statistical methods are used: Factor analysis (i.e. the Principal component method, as a method of factor extraction in factor analysis), linear aggregation and Wilcoxon signed ranks test.

\section{SUSTAINABLE DEVELOPMENT CONCEPT}

Interest in environmental issues, the existence of possible limits of growth and future economic growth are beginning at early seventies of the last century. At that time, the first warnings about future development by eminent experts have appeared (Meadows, Meadows, Randers \& Behrens, 1972). The formation of numerous ecological organizations at the national and international level has begun. "First of all, this was influenced by the unfavourable state of the environment caused by economic growth, but also by the fear of the scarcity of the basic natural resources on which modern production is based." (Jovanović-Gavrilović, 2006 , p. 53) In addition to the issues of economic growth, sufficient resources of the natural environment, pollution, awareness of the future generations and the heritage that will be left to them are raised.

In response to this concern, a new concept of development emerged sustainable development. "The basic idea is that sustainable development goes beyond the concept of economic growth solely and refers to tangible as well as intangible aspects and needs of living" (Bankova, 2016, p. 81). The basis of this concept is the simultaneous recognition and inclusion of three key dimensions - economic, environmental and social. In order to achieve the goals of sustainable development, there is a need for interconnectivity and complementarity between all three dimensions, i.e. pillars of sustainable development. It is also important to respect the rule that all three pillars have an equal contribution to the realization of the concept of sustainable development. In policy development, no pillar should be viewed separately from others. If each pillar was viewed separately, from different perspectives, it is certain that some would gain more importance or priority than others (Giddings, Hopwood \& O'Brien, 2002, p. 189). If all three components were equal, it would mean that there is a trade-off between them.

The essence of the concept of sustainable development is the care of heritage. This implies that the quality of life of future generations must 
not be worse than the quality of life of today's generation. This idea is best promoted by the definition of sustainable development formulated by the World Commission on Environment and Development (WCED), at the Brundtland Conference in 1987. At this conference, sustainable development was defined as "development that meets the needs of the present generation without compromising the ability of future generations to meet their needs." There are several characteristics of the concept of sustainable development arising from this definition. These are the most important ones (Hussen, 2004, p. 269):

- Equality. The definition of sustainable development clearly highlights the issue of equality. The care for future generations and the demand for at least equal quality of life of today's and future generations explicitly emphasize this sustainability characteristic.

- Ethics. The needs of the present generation must not be met for the detriment of the benefits of future generations. This characteristic of sustainable development is known as intergenerational justice.

- Efficiency. Economic efficiency is one of the key conditions for optimal use of natural resources.

Nowadays, sustainable development represents a contemporary concept of development incorporated into all policies, strategies and development programs.

\section{CONCEPTS OF COMPETITIVENESS AND SUSTAINABLE COMPETITIVENESS}

Competitiveness is the ability to survive long-term in the conditions of a market economy, that is, the ability of the country to achieve success on the world market, which implies a highly productive economy and a better living standard of the population (Cvjetićanin, 2003, p. 88). According to the definition of The Organisation for Economic Co-operation and Development (OECD) "competitiveness is a measure of a country's advantage or disadvantage in selling its products in international markets" (OECD). It can be said that competitiveness implies ensuring stability and sustainability of growth and development and can be viewed at three levels: at the enterprise, sector, and national level 'Cvjetićanin, 2003, p. 88).

The World Economic Forum deals with the definition, measurement and ranking of the level of competitiveness of national economies (WEF). World Economic Forum defines competitiveness as "the set of institutions, policies, and factors that determine the level of productivity of an economy, which in turn sets the level of prosperity that the economy can achieve" (WEF, 2017-2018, p. 11). The competitiveness of the national economy is measured with the help of a large number of indicators that are included in the calculation of the subindexes of competitiveness and finally determine the value of the overall, i.e. composite index of competitiveness. Composite 
index - Global Competitiveness Index (GCI) was developed by Xavier Sala-i-Martín in collaboration with the Forum since 2005. The GCI combines more than hundred indicators that capture concepts that matter for productivity and long-term prosperity (WEF, 2014-2015).

Over the years, the World Economic Forum has changed the methodology for measuring competitiveness, as the result of the efforts to take into account all the new changes in the modern business and political environment (Savić, 2008, p. 379). "Competitiveness is not only about performance of a nation, it is also about the environmental and social performance. The synergy between them will create sustainable competitiveness" (Herciu, Ogrean, 2014, p. 651). Thus, in addition to economic performance, there is a need to look at the "soft" factors of competitiveness, such as environment, quality of life, technology, knowledge, etc. (Balkyte, Tvaronaviciene, 2010, p. 344). Since interest in implementing the concept of sustainable development and measuring its achieved level has been gaining increasing attention, WEF has created a framework for assessing sustainable competitiveness in 2011. "Contribution to the operational use of the concept of sustainability, especially with regard to the simultaneous treatment of its economic, social and environmental dimensions is an approach to measure the competitiveness of countries by World Economic Forum" (Cvetanović, Despotović \& Nedić, 2016, p. 336; Filipović, Despotović, 2014, p. 80). In this way, a new context of competitiveness analysis is introduced which is meeting the challenges of the concept of sustainable development. "The concept of competitiveness is a multifaceted term that has evolved over the years based on sustainable development paradigms from responsible competitiveness to sustainable competitiveness. The latest economic literature refers to the concept of sustainable competitiveness by expanding the traditional importance of competitiveness" (Urbaniec, 2016, p. 39).

In 2015, WEF presented Sustainability-Adjusted GCI in its Global Competitiveness Report (Figure 1). GCI is corrected by factors that present social and environmental sustainability. The definition of competitiveness has been extended and WEF "define sustainable competitiveness as the set of institutions, policies, and factors that make a nation productive over the longer term while ensuring social and environmental sustainability" (WEF, 2014-2015, p. 55).

Competition is a necessary condition for future growth and development. However, the care for the existence of scarcity of resources and the preservation of their base so that future generations will have the same level of wellbeing as the present generation, requires the incorporation of environmental and social issues and problems into the concept of competitiveness. Only on that way is it possible to maintain competitiveness in the long run. "This model presents a framework for adapting the measurement of global competitiveness by factors including 
social and environmental dimensions of sustainable development. The competitiveness model plays a key role as a factor of social welfare, where a high level of competitiveness is crucial for sustained prosperity" (Urbaniec, 2016, p. 40).

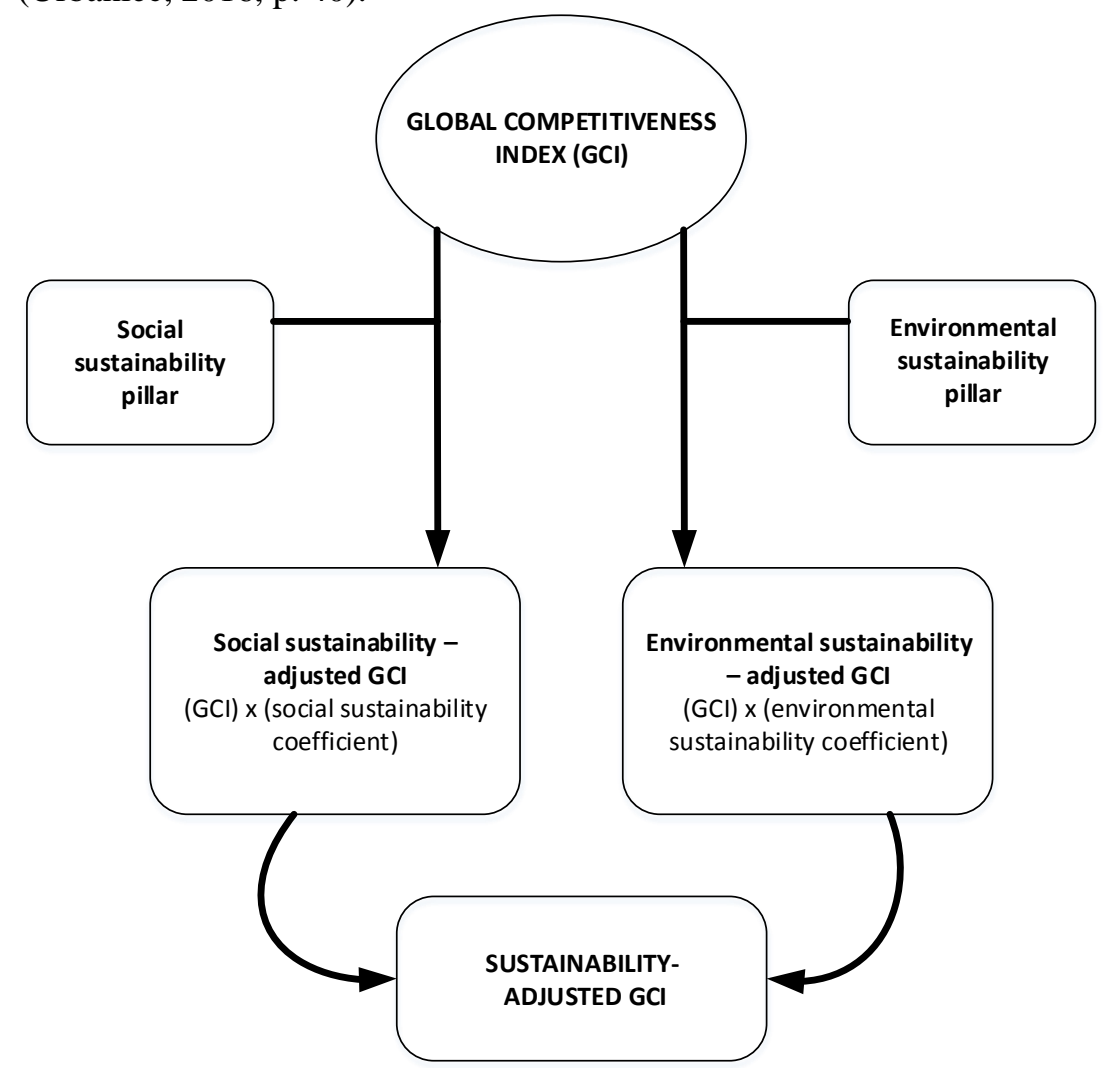

Figure 1 The structure of the sustainability-adjusted GCI

Source: WEF, The Global Competitiveness Report 2014-2015, p. 64.

Indicators of sustainable development and sustainable competitiveness are an effective instrument in the strategic determination of countries to consistently implement the concept of sustainable development. "Generally, globalization, economic dynamism and social progress, sustainability and competitiveness go hand-in-hand. The different sets of competitive advantages interact and reinforce each other. In this context, it should be pointed out that there is a need of research initiatives to develop further the concept of "sustainable competitiveness" and the new theoretical models, with much focus on how international globalization, economic growth, sustainable development, wellbeing and competitiveness interact" (Balkyte, Tvaronaviciene, 2010, p. 359). 


\section{THE GLOBAL SUSTAINABLE COMPETITIVENESS INDEX}

In order to assess progress in achieving competitiveness through the integration of all three dimensions of sustainable development environmental, economic and social, SolAbility has developed the Global Sustainable Competitiveness Index (GSCI). Definition of sustainable competitiveness managed by SolAbility "means that current wealth levels are not in danger of being reduced or diminished through over-exploitation of resources (i.e. natural and human resources), the lack of innovative edge required to compete in the globalised markets (i.e. education), or the discrimination, marginalisation or exploitation of segments of a society" (SolAbility, p. 8). That is, the methodology of sustainable competitiveness implies unhindered satisfaction of the needs of the present generation, while maintaining or even increasing the wealth and prosperity of future generations.

The Global Sustainable Competitiveness Index methodology is based on five pillars which have equal importance in composite indicator of sustainable competitiveness determination (SolAbility, p. 7):

- Natural Capital: the given natural environment, including the availability of resources, and the level of the depletion of those resources.

- Social Capital: health, security, freedom, equality and life satisfaction within a country.

- Resource Management: the efficiency of using available resources as a measurement of operational competitiveness in a resourceconstraint world.

- Intellectual Capital: the capability to generate wealth and jobs through innovation and value-added industries in the globalized markets.

- Governance Efficiency: results of core state areas and investments - infrastructure, market and employment structure, the provision of a framework for sustained and sustainable wealth generation.

The starting assumption of the methodology is that all pillars interact and influence each other. Each of the pillars contains a number of variables, or indicators of sustainable competitiveness. The composite index is based on a total of 106 indicators. Figure 1 illustrates the GSCI pillars and basic indicators of sustainable competitiveness.

In the model of sustainable competitiveness, pillars are positioned in the pyramidal system so that the higher level has an impact on the state at the lower pyramidal level. At the top of the pyramidal system is Natural capital, followed by Resource intensity, Social capital, Intellectual capital and Governance. 


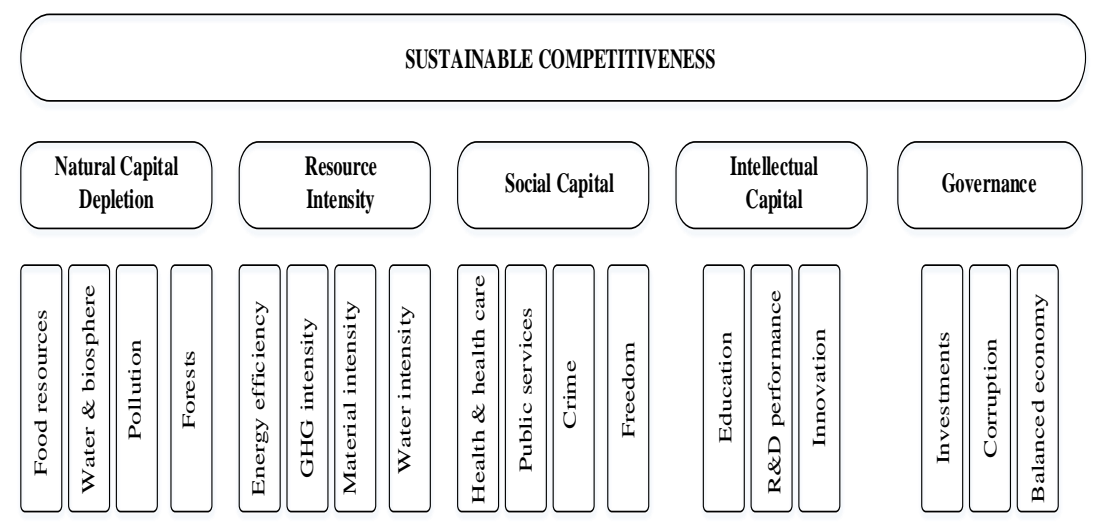

Figure 1 The Sustainable Competitiveness Index

Source: The competitiveness of sustainability, www.solability.com

Some of the indicators within the Natural resources pillar are: renewable freshwater availability, electricity from hydropower, forest area, arable land, land degradation, population density, average rainfall, fertilizer consumption, tourist attractiveness, etc. Indicators that reflect pillar Resource intensity are: energy per capita, $\mathrm{CO} 2$ emissions, electricity from coal, electricity from oil, air pollution, hazardous waste per GDP, water usage per capita, waste per capita... Pillar named Social capital consists of indicators: number of doctors per 1000 people, hospital beds availability, number of nurses per 1000 people, child mortality, public health spending, suicide rate, life expectancy, GINI coefficient, women in parliament... Indicators within the pillar Intellectual capital are: primary education completion, secondary education enrolment, spending on education, patent application, R\&D spending, high tech exports... Pillar Governance efficiency contains the following indicators: internet availability, employment in the manufacturing sector, unemployment, investments, quality of public services, government debt, imports, access to electricity... Characteristic of this model of sustainable competitiveness is that quantitative indicators are used exclusively in calculating the composite index in order to avoid subjectivity in their assessment.

\section{RESEARCH METHODOLOGY AND HYPOTHESIS}

Composite indexes, including the above mentioned indicators, have been identified as a useful tool for measurement and evaluation. Since the creation of the first composite index, there has been controversy about their use until now. In addition to specifying good use of composite indexes, there is also a lot of warnings about possible errors in the formation and application of composite indexes, but these warnings mostly relate to problems of 
aggregation and weighing. The majority of composite indexes, GSCI also, rely on equal weighing. However, this method often conceals the lack of the statistical basis in assigning weight coefficients. The emphasis in this paper is on the effects of applying statistical methods in the composite indexes creation.

\section{Rules and Approaches in the Weights Calculation}

Although equal weighing certainly represents an explicit weighting scheme, a priori decision to apply an equal weighing technique for methodological purposes makes the choice of weights seemingly less subjective (Sharpe, 2004). It does not necessarily mean that the differential weighing necessarily corresponds to the identification of different weights, but rather corresponds to the choice of the most adequate approach with the aim of "identifying the weights among all identified" (Nardo et al, 2005). Assigning differential weights can be a subject of controversy, especially if the decision is not supported by theoretical considerations that attach importance to each of the indicators.

It is necessary to emphasize that there is no generally accepted methodology for determining weights. In literature and practice, it is basically possible to distinguish two basic approaches: objective and subjective. Each of the weighing methods has its advantages and disadvantages in terms of potentiating one and marginalizing other factors that influence the expression of the preference of the decision-makers. For this reason, the need for combining several methods of determining weights is imposed. From the aspect of the problem of differential weights calculation, statistical methods have always been representative and respected, above all, correlation analysis and Principal components analysis.

It should be emphasized that there are several methods of aggregating the weighed values of the indicators. The linear aggregation method is applied when all individual indicators are expressed in the same measurement units, provided that some mathematical properties are respected. The method of geometric aggregation is more convenient if in the formation of a composite index it is desired to maintain a certain degree of noncompliance between individual indicators or dimensions.

\section{Factor Analysis as a Basis for Weight Coefficients Determination}

Principal component analysis, or more specifically Factor analysis, group variables that are collinear to form a new factor or attribute capable of capturing as much of common information of those attributes as possible (https://ec.europa.eu/jrc/en/coin/10-step-guide/step-6). The purpose of applying this multivariate analysis method is to reduce the original number of variables to a smaller number of new latent variables (factors) that are highly correlated with the original variables. Due to this, this 
method is often used in the construction of composite indices (see Greco et al. 2019).

Factor analysis provides several possibilities for weights determination. The first possibility occurs in the first phase, which covers constructing a correlation matrix. The correlation matrix contains the coefficients of simple linear correlation of each pair of variables, which represent the basis for conducting factor analysis. One of the prerequisites for conducting factor analysis is the correlation between source variables, and the correlation matrix is the basis for detecting groups of associated variables. At this stage, KMO (Kaiser-Mayer-Olkin) statistics, as a measure of sample adequacy, is also calculated. This statistics compares the size of the observed correlation coefficients and the partial correlation coefficients. The low values of these statistics indicate that the correlations between the pairs of original variables cannot be explained by other variables and that there is little justification for applying factor analysis.

Except for the value of the Kaiser-Meyer-Olkin measure can be calculated for the entire matrix, it can also be calculated for individual variables. In this way, it is possible to examine the suitability of each individual variable in the analysis and can exclude variables that do not have a sufficiently large value. This increases the value of the KaiserMeyer-Olkin measure of the entire matrix. The Kaiser-Meyer-Olkin measure can be valued in a closed interval from 0 to 1 . These values can serve as the basis for determining the weight coefficients of each attribute (the second possibility).

The third possibility for determining weight coefficients (applied in this paper) occur in the fourth step in the factor analysis process. It is possible to construct the weights from the matrix of factor loadings after rotation, given that the square of factor loading represents the proportion of the total unit variance of the attribute which is explained by the factor. Notice that different methods for extraction of principal components imply different weights. The rest of the variance, which is not explained by the factor or factors involved, that is, the difference in the total variance and the value of the square of the factor loadings is a specific part of the variance, unique for each individual attribute.

Having in mind the object and purpose of the research, the key hypothesis in this paper would be that the application of factor analysis in the weighing dimensions in the structure of GSCI affects the global level of sustainable competitiveness. Information base for this analysis consists of data in the SolAbility Report 2017. This report contains information on the 106 dimensions of the sustainable competitiveness of 180 countries in the world. 


\section{RESEARCH RESULTS}

In line with the goal of the research, factor analysis has been applied on five dimensions included in the Global Sustainable Competitiveness Index. Firstly, data adequacy check was performed in order to confirm compliance with conditions for factor analysis application. Based on the Kaiser-Meyer-Olkin Measurement of Sampling Adequacy, which was higher than 0.5 (Table 1), it can be concluded that the conditions for the factor analysis application are met. Also, based on realized significance level of the Bartlett's Test of Sphericity (by which the correlation matrix was tested), it can be concluded that the data are suitable for the application of factor analysis.

Table 1 KMO and Bartlett's Test results

\begin{tabular}{llr}
\hline Kaiser-Meyer-Olkin Measure of Sampling Adequacy. & 0.699 \\
\hline Bartlett's Test of Sphericity & Approx. Chi-Square & 306.169 \\
& Degrees of freedom & 10 \\
& Significance & 0.000 \\
\hline
\end{tabular}

Source: Authors calculation

After checking the adequacy of the data set, the adequacy of each of the dimensions (pillars within GSCI) that would be included in the factor analysis was also checked. Measures of Sampling Adequacy are shown in the Table 2.

Table 2 Measures of Sampling Adequacy (MSA) for dimensions

\begin{tabular}{lc}
\hline Dimension & Measure of Sampling Adequacy \\
\hline Natural Capital & 0.518 \\
Resource Intensity & 0.714 \\
Intellectual Capital & 0.708 \\
Government Capabilities & 0.763 \\
Social Capital & 0.508 \\
\hline \multicolumn{2}{c}{ Source: Authors calculation }
\end{tabular}

Based on the Measures of Sampling Adequacy values, it has been concluded that each of the dimensions meets the requirement to be included in the factor analysis, since all MSA values are greater than 0.5 (Tabachnick, Fidell, 2013).

After checking the assumptions, factor analysis was carried out. Within the factor analysis, the Principal Component Method was applied, whereby within factor extraction definition, criteria for number of extracted factors were initial eigenvalue higher than 1 and share of explained variance higher than 60\% (Tabachnick, Fidell, 2013). 
Table 3 Realized values of factor extraction criteria

\begin{tabular}{|c|c|c|c|c|c|c|c|c|c|}
\hline \multirow[b]{2}{*}{ Component } & \multicolumn{3}{|c|}{ Initial Eigenvalues } & \multicolumn{3}{|c|}{$\begin{array}{c}\text { Extraction Sums of } \\
\text { Squared Loadings }\end{array}$} & \multicolumn{3}{|c|}{$\begin{array}{l}\text { Rotation Sums of } \\
\text { Squared Loadings }\end{array}$} \\
\hline & Total & $\begin{array}{c}\% \text { of } \\
\text { Variance }\end{array}$ & $\begin{array}{c}\text { Cumulative } \\
\%\end{array}$ & Total & $\begin{array}{c}\% \text { of } \\
\text { Variance }\end{array}$ & $\begin{array}{c}\text { Cumulative } \\
\%\end{array}$ & Total & $\begin{array}{c}\% \text { of } \\
\text { Variance }\end{array}$ & $\begin{array}{c}\text { Cumulative } \\
\%\end{array}$ \\
\hline 1 & 2.455 & 49.109 & 49.109 & 2.455 & 49.109 & 49.109 & 2.389 & 47.785 & 47.785 \\
\hline 2 & 1.294 & 25.887 & 74.996 & 1.294 & 25.887 & 74.996 & 1.361 & 27.211 & 74.996 \\
\hline 3 & .671 & 13.415 & 88.411 & & & & & & \\
\hline 4 & .324 & 6.476 & 94.888 & & & & & & \\
\hline 5 & .256 & 5.112 & 100.000 & & & & & & \\
\hline
\end{tabular}

According to the above mentioned criteria, two factors (main components) were extracted. The first component explains $49.109 \%$ of the total variance in the observed data, while the second component explains additional $25.887 \%$ of total variance. Thus, the total variance explained by those two factors amounts $74.996 \%$ (Table 3), which is in line with the set criteria.

After factors extraction, Varimax rotation has been performed. Factor loadings, which show the direction and level of correlation between dimensions (pillars) and the defined component (factor) after rotation, are shown in the second and the third column of Table 4.

Table 4 Factor loadings

\begin{tabular}{lccc}
\hline \multirow{2}{*}{ Dimension } & \multicolumn{2}{c}{ Component } & \multirow{2}{*}{ Weights } \\
\cline { 2 - 3 } & 1 & 2 & \\
\hline Natural Capital & & 0.818 & 0.1726 \\
Resource Intensity & 0.894 & & 0.2192 \\
Intellectual Capital & 0.910 & & 0.2232 \\
Government Capabilities & 0.866 & & 0.2124 \\
Social Capital & & 0.816 & 0.1726 \\
\hline
\end{tabular}

Source: Authors calculation

The weight coefficients have been calculated according to values of factor loadings and same time percentage of explained variance. Dimensions Resource Intensity, Intellectual Capital and Government Capabilities (First Component) explain $49.109 \%$ of total variance, while dimensions Natural Capital and Social Capital (Second Component) explain 25.87\% of total variance. Within the first component, the largest share is related to Intellectual Capital, while the remaining two dimensions have equal participation. Dimensions Natural Capital and Social Capital are equally correlated with second component extracted in factor analysis. Based on all this criteria, the appropriate weights for each of the dimensions within the GSCI are calculated (Table 4). 
It should be noted that this is not a new composite indicator, but rather a different approach in determining the weights in the existing indicator. Thus, a high level of correlation with the current GSCI (Spearman's rho correlation coefficient $=0.991$, Sig. $<0.0001$ ) could be expected.

\section{DISCUSION}

Changing the methodology of calculating the GSCI, reflected in different weight coefficients assigned to individual dimensions, leads to a significant change in overall sustainable competitiveness. Table 5 shows a comparative overview of the descriptive measures for the GSCI score according to the current methodology (applied in reports) and according to the proposed methodology.

Table 5 Descriptive measures of GSCI scores - comparative preview

\begin{tabular}{lccccc}
\hline Variable & $\mathrm{N}$ & Minimum & Maximum & Mean & $\begin{array}{c}\text { Std. } \\
\text { Deviation }\end{array}$ \\
\hline $\begin{array}{l}\text { GSCI score - Report } \\
\text { (current methodology) }\end{array}$ & 180 & 30.20 & 60.50 & 43.67 & 5.83 \\
GSCI score - new methodology & 180 & 30.05 & 60.44 & 43.49 & 6.11 \\
\hline \multicolumn{5}{c}{ Source: Authors calculation }
\end{tabular}

Based on descriptive measures, it can be concluded that the change in the GSCI calculation methodology would change the min and max values of the GSCI, as well as the average GSCI value from 3,821 to 4,074 . However, the variability will also increase. Namely, according to the new methodology, the average deviation of each country's score from the average GSCI score would be 6.11, which is higher than the deviation according to the current methodology.

Since the assumptions for applying the parameter tests were not met, Wilcoxon Signed Ranks Test (Wilcoxon, 1945), as a non-parametric alternative of the dependent samples t-test, was applied in order to test the significance of differences in the average values of GSCI according to the current and new methodology. Decrease in the average GSCI value of 0.174 after the application of the new methodology was found to be statistically significant $(Z=-3,024, p$-value $=0.002)$. This confirms the hypothesis that changing the methodology significantly influences the average measured level of sustainable competitiveness of analyzed countries.

The change in methodology results in a change in the rank of countries for which GSCI is accounted for. Firstly, an overview of the changes in the top 10 positions on the ranking list is given (Table 6). The position of the first three countries on the list would not change, but South Korea and Germany, which according to the current methodology 
are ranked 16th and 14th respectively, would be included in the 10 best ranked countries.

Table 6 Top 10 countries - comparative preview

\begin{tabular}{|c|c|c|c|}
\hline \multicolumn{2}{|c|}{$\begin{array}{c}\text { Top } 10 \text { countries } \\
\text { according to GSCI report }\end{array}$} & \multicolumn{2}{|c|}{$\begin{array}{c}\text { Top } 10 \text { countries } \\
\text { according to new methodology }\end{array}$} \\
\hline Country & Rank & Country & Rank \\
\hline Sweden & 1 & Sweden & 1 \\
\hline Norway & 2 & Norway & 2 \\
\hline Iceland & 3 & Iceland & 3 \\
\hline Finland & 4 & Denmark & 4 \\
\hline Denmark & 5 & Finland & 5 \\
\hline Ireland & 6 & Switzerland & 6 \\
\hline Switzerland & 7 & Ireland & 7 \\
\hline Austria & 8 & Austria & 8 \\
\hline Latvia & 9 & South Korea & 9 \\
\hline Estonia & 10 & Germany & 10 \\
\hline
\end{tabular}

It can be noted that changes in the methodology would cause positive and negative changes in the ranking of countries towards sustainable competitiveness. From a total of 180 countries analyzed, 76 of them would improve their position in the rankings, while 84 would record negative changes on the list. Table 7 shows the countries where the highest positive change occurred in the ranking. The biggest positive change in the ranking would be reflecting Bahrain, which would reach the 116th position from the 137th position. Global Sustainable Competitiveness Index score for this country, according to the current methodology based on equal weights, is 39.60 , but after unequal weighing the score is 40.47 . In general, the biggest positive changes at the ranking list would be recorded in countries that have lower scores of dimensions Natural Capital and Social Capital.

Table 7 Countries with the highest positive change

\begin{tabular}{lclc}
\hline Country & Difference & Country & Difference \\
\hline Bahrain & 21 & Tunisia & 11 \\
Jordan & 19 & Cyprus & 11 \\
Oman & 14 & Kuwait & 11 \\
Turkmenistan & 14 & Azerbaijan & 11 \\
Singapore & 13 & St. Kitts and Nevis & 11 \\
Maldives & 13 & India & 10 \\
Sri Lanka & 13 & Trinidad and Tobago & 10 \\
Cuba & 12 & Lebanon & 10 \\
\hline
\end{tabular}

Source: Authors calculation 
The biggest negative change was reflected in the Democratic Republic of Congo, with the GSCI scoring from 41.90 down to 39.96, which caused a decrease in the rankings for 21 positions. Interestingly, Brazil's position is lower by as much as 10 , as it moves from position 42 to position 52 , with GSCI scores reduced by 0.81 points.

Methodological changes in GSCI calculation, i.e. the allocation of adequate weights to the dimensions of sustainable competitiveness would positively affect the position of the Republic of Serbia. The score increase from 46.80 to 47.32 would lead to the position improvement on the list. Namely, from the 50th place Serbia would reach 45th place, which, given the changes in the countries from the region, is the biggest improvement.

Twenty countries would not change their existing ranking by a new methodology. Majority of them are European countries, such as Sweden, Norway, Austria, Luxemburg Belgium, Spain etc. Those countries are, in the same time, high ranked on the list according to GSCI score.

\section{CONCLUSION}

In order to assess progress in achieving competitiveness through the integration of all dimensions of sustainable development SolAbility has developed the Global Sustainable Competitiveness Index (GSCI). The GSCI methodology is based on five pillars which have equally importance in composite indicator of sustainable competitiveness determination: Natural Capital, Social Capital, Resource Management, Intellectual Capital and Governance Efficiency.

The use of equal weighting in the creation of composite indexes is, according to the opinion of a large number of experts, the one of the key deficiencies of these indicators. Most critics consider that the calculation of the weights to be assigned to individual dimensions in the structure of the composite index should be based on one of the statistical methods or methods of multi-criteria analysis. Realizing this as a recommendation, Principal component analysis was applied in this paper in order to determine the relative importance of certain dimensions in the structure of the GSCI.

The application of this method has led to significant changes in the ranking of countries involved in measuring sustainable competitiveness. From a total of 180 countries analyzed, 76 of them would improve their position in the rankings, while 84 would record negative changes on the list. The major positive changes in the ranking list would be recorded in countries that have lower scores of dimensions Natural Capital and Social Capital. Majority of high ranked countries, mostly European countries, did not change their existing ranking by a new methodology. The observed changes in the ranking list caused by methodological changes will serve as the basis for further and deeper analysis of the place and the role of individual indicators in the structure of the Global Sustainable Competitiveness Index. 


\section{REFERENCES}

Balkyte, A. \& Tvaronaviciene, M. (2010). Perception of competitiveness in the context of sustainable development: facets of "Sustainable competitiveness", Journal of Business Economics and Management, 11(2), 341-365. doi:10.3846/jbem.2010.17.

Bankova, Y. (2016). Sustainable competitiveness of Balkan countries, Intternattiionall sciienttiiffiic confference - ERAZ 2016: Knowledge based sustainable economic development, $(81-86)$.

Competence Centre on Composite Indicators and Scoreboards. 10-Step guide for the construction of a composite indicator. Retrieved from: https://ec.europa.eu/jrc/ en/coin/10-step-guide/step-6.

Cvetanović, S., Despotović, D. \& Nedić, V. (2016). Social dimension of sustainable competitiveness of Serbia and selected European countries, Facta Universitatis, Series: Economics and Organization, 13(4), 335-350. doi:10.22190/ FUEO1604335C.

Cvjetićanin, D. (2003). Competetiveness concept and Serbian economy, Ekonomist, 39(1), p. 88.

Filipović, M. \& Despotović, D. (2014). Analysis of Sustainable Competitiveness of European Countries in 2013, Ekonomika, 60(4), 77-91. https://www.ekonomika. org.rs/sr/PDF/ekonomika/2014/4clanci/8.pdf

Giddings, B., Hopwood, B. \& O’Brien, G. (2002). Environment, Economy and Society: Fitting them Together into Sustainable Development, Sustainable Development, No. 10, 187-196, Wiley InterScience (www.interscience.wiley.com), DOI: $10.1002 /$ sd. 199

Greco S., Ishizaka, A., Tasiou M. \& Torrisi, G. (2019). On the Methodological Framework of Composite Indices: A Review of the Issues of Weighting, Aggregation, and Robustness. Social Indicators Research, 141(1), 61-94. https://doi.org/10.1007/ s11205-017-1832-9.

Herciu, M. \& Ogrean, C. (2014). An Overview on European Union Sustainable Competitiveness, Procedia Economics and Finance, 16, 651-656. https://doi.org/10.1016/S2212-5671(14)00853-3

Hussen, A. (2004). Principles of Environmental Economics, New York: Routledge.

Јовановић-Гавриловић, Б. (2006). Одржив развој - суштина концепта и могућност мерења у Одржив развој у СЦГ: институционално прилагођавање решенима и пракси у EУ [Sustainable development - the essence of the concept and the possibility of measurement In: Sustainable development in SCG: Institutional adaptation to EU solutions and practices]. Beograd: Ekonomski fakultet.

Meadows, D.H., Meadows, D.L., Randers, J. \& Behrens, W.W. (1972). The Limits to Growth: A Report for the Club of Rome's project on the Predicament of Mankind, New York: Earth Island, Universe Books.

OECD Competitiveness (In International Trade), Retrieved from: https://stats.oecd.org/ glossary/detail. asp?ID=399. Acceseed on: 25 May 2019.

World Commission on Environment and Development (1987). Our Common Future, Oxford: Oxford University Press.

Savić, N. (2008). Competitiveness of Serbian economy, Transition, achieving EU and linked topics, Kopaonik business forum 2008, Society of Economists of Serbia, Belgrade.

Tabachnick, B. \& Fidell L. (2013). Using multivariate statistics. Boston: Pearson/Allyn \& Bacon.

Nardo, M., Saisana, M., Saltelli, A. \& Tarantola S. (2005). Tools for composite indicators building. European commission, EUR 21682 EN. Ispra: Joint Research Centre. 
Urbaniec, M. (2016). Sustainable competitiveness. Opportunities and challenges for Pland's economy, Ekonomia, 4(59), p. (34-51) 39 (according to Mac Gillivray A., Sabapathy J., Zadek S., Responsible Competitiveness Index 2003 -Aligning corporate responsibility and the competitiveness of nations. AccountAbility, Denmark 2003; The competitiveness of sustainability, www.solability.com)

Wilcoxon, F. (1945). Individual comparisons by ranking methods. Biometrics Bulletin. 1(6), 80-83. http://links.jstor.org/sici?sici=00994987\%28194512\%291\%3A6\% 3C80\%3 AICBRM\%3E2.0.CO\%3B2-P

World Economic Forum (2015).The Global Competitiveness Report 2014-2015. http://www3.weforum.org/docs/WEF_GlobalCompetitivenessReport_201415.pdf.

\title{
ЕФЕКТИ ПРИМЕНЕ СТАТИСТИЧКИХ МЕТОДА У КРЕИРАЫУ ГЛОБАЛНОГ ИНДЕКСА ОДРЖИВЕ КОНКУРЕНТНОСТИ
}

\author{
Весна Јанковић Милић, Соња Јовановић \\ Универзитет у Нишу, Економски факултет, Ниш, Србија
}

Резиме

У савременој литератури могу се наћи бројне дефиниције, значења и тумачења концепта одрживог развоја. Данас, одрживи развој представља савремени концепт развоја који је инкорпориран у све политике, стратегије и програме развоја. Како би се проценио напредак у постизању конкурентности, али кроз интеграцију све три димензије одрживог развоја - еколошке, економске и социјалне - организација SolAbility je развила Глобални индекс одрживе конкурентности (GSCI). Методологија глобалног индекса одрживе конкурентности заснива се на пет стубова који имају подједнаку важност у композитном показатељу одрживе конкурентности: природни капитал, друштвени капитал, управљање ресурсима, интелектуални капитал, ефикасност управљања.

GSCI, као и многи други композитни индекси, ослања се на једнаке пондере који се додељују свим индикаторима које индекс садржи. Међутим, овакав начин конструисања композитних индекса карактерише недостатак примене статистичких полазишта у одређивању тежинских коефицијената (пондера). Нагласак у овом раду је на ефектима примене статистичких метода у креирању композитних индекса. Циљ је давање предлога нове методологије за израчунавање Глобалног индекса одрживе конкурентности на основу различитог пондерисања или придавања значаја компонентама укљученим у Индекс. Метод факторске анализе примењен је на све компоненте Глобалног индекса одрживе конкурентности. Информациону основу истраживања чини база података организације SolAbility. У овом истраживању коришћене су следеће статистичке методе: Факторска анализа (тј. метод главних компонената, примењен у фази екстракције фактора у факторској анализи), линеарна агрегација и Wilcoxon тест-рангова.

Примена методе главних компонената довела би до значајних промена у рангирању земаља које су укључене у мерење одрживе конкурентности. Од укупно 180 анализираних земаља, њих 76 побољшало би своју позицију на ранг-листи, док би 84 земље забележиле негативне промене на ранг-листи. Највеће позитивне 
824

промене на ранг-листи имале би земље са нижим оцењеним вредностима природног и социјалног капитала. Већина високо рангираних земаља, углавном европских земаља, не би променила свој постојећи ранг у складу са новом методологијом. У раду су изнета само нека запажања приликом коришћења коригованог GSCI и иста представљају повод за реалније и детаљније вредновање компонената композитног показатеља одрживе конкурентности. 